\title{
Development of Rainfall Intensity Duration Frequency Curves for Mumbai City, India
}

\author{
P. E. Zope, Eldho T. I. ${ }^{*}$ V. Jothiprakash \\ Department of Civil Engineering, Indian Institute of Technology Bombay, Mumbai, India \\ Email: "eldho@civil.iitb.ac.in
}

Received 20 May 2016; accepted 20 June 2016; published 24 June 2016

Copyright $\odot 2016$ by authors and Scientific Research Publishing Inc.

This work is licensed under the Creative Commons Attribution International License (CC BY). http://creativecommons.org/licenses/by/4.0/

(c) () 0 pen Access

\begin{abstract}
The change in rainfall pattern and intensity is becoming a great concern for hydrologic engineers and planners. Many parts of the world are experiencing extreme rainfall events such as experienced on $26^{\text {th }}$ July 2005 in Mumbai, India. For the appropriate design and planning of urban drainage system in an area, Intensity Duration Frequency (IDF) curves for given rainfall conditions are required. The aim of the present study is to derive the IDF curves for the rainfall in the Mumbai city, Maharashtra, India. Observed rainfall data from 1901 pertaining to Colaba and from 1951 of the Santacruz rain gauge stations in Mumbai are used in the present study to derive the IDF curves. Initially, the proposed IDF curves are derived using an empirical equation (Kothyari and Garde), by using probability distribution for annual maximum rainfall and then IDF curves are derived by modifying the equation. IDF curves developed by the modified equation gives good results in the changing hydrologic conditions and are compatible even with the extreme rainfall of $26^{\text {th }}$ July 2005 in Mumbai.
\end{abstract}

\section{Keywords}

Rainfall, Intensity, Duration, Return Period, Frequency, IDF Curves

\section{Introduction}

In many parts of the world, flooding is probably the most severe hazard among the natural hazards occurring due to change in rainfall pattern. Development of rainfall Intensity-Duration-Frequency (IDF) relationship is a primary basic input for the design of the storm water drainage system for cities [1]. The rainfall depths derived from the intensity duration frequency relationship is being used by water resource managers for planning, designing and operation of water resource related projects [2]. To ascertain the hydrologic risks, assessment of ex-

${ }^{*}$ Corresponding author.

How to cite this paper: Zope, P.E., Eldho T.I. and Jothiprakash, V. (2016) Development of Rainfall Intensity Duration Frequency Curves for Mumbai City, India. Journal of Water Resource and Protection, 8, 756-765. 
treme precipitation and establishment of IDF curves are important [3] [4]. The relationship between rainfall intensity and duration was demonstrated by Kuichling [5] having maximum discharges of runoff. A generalized IDF formula for any location in the United States was presented using three basic rainfall depths, that is, $R_{1}^{10}$ (1 h, 10-year rainfall depth), $R_{24}^{10}$ (24 h, 10-year rainfall depth), and $R_{1}^{100}$ (1 h, 100-year rainfall depth) [6]-[8]. Kothyari and Garde [9] developed a general relationship between the rainfall intensity, duration $\left(P_{24}^{2}\right)$ and frequency with the Indian conditions. They developed the equation for IDF curves using the rainfall data of 78 rain gauge stations from all over India considering the value of mean annual rainfall $(R)$ for $24 \mathrm{hr}$, and two-year rainfall, $R_{24}^{2}$. IDF is a statistical relationship between the rainfall intensity $(i)$, the duration $(d)$, and the return period $(T)$ [2]. This approach was further extended by combining high frequency rainfall extremes having long term daily information and derived IDF curves taking into consideration of a short instrumental data set for time less than one day [10]. IDF curves for part of Saudi Arabia were developed by using statistical distribution techniques for different return periods [11].

While designing the new drainage system, proper information having IDF relationship reflecting recent hydrologic changes has to be used as design criteria [12]. Mumbai being the coastal city, surrounded by sea and creek is vulnerable to flooding when the high intensity of rainfall coincides with high tidal conditions. Therefore proper knowledge of rainfall intensity should be available for the proper and efficient design of the storm water drainage system. Earlier, Chawathe et al. [1] had presented a detailed rainfall analysis for Mumbai. It was done with the data taken for 24 and 33 years for Colaba and Santacruz rain gauge station respectively. Zope et al. [13] carried out the spatio - temporal rainfall variation for Mumbai city. Further it is felt that there is a necessity and need to update the IDF relationship, especially depending on today's changing hydrological conditions [14].

The aim of the present study is to develop the IDF rainfall curves for the Mumbai city using longer length of observed rainfall data. Initially, the proposed IDF curves are modeled using the empirical relationship developed by Kothyari and Garde [9], using the probability distribution method for annual maximum rainfall and then the same equation has been modified to derive the IDF curves by incorporating the varying return period concept. The results obtained were compared with respect to the changing hydrological conditions, especially with the extreme rainfall observed on $26^{\text {th }}$ July 2005 in the Mumbai region.

\section{Case Study Area and Hydro Metrological Features}

Mumbai (lat. $18.50^{\circ} \mathrm{N}$, long. $72.52^{\circ} \mathrm{E}$ ), (Figure 1) being the capital of Maharashtra state and financial trade centre and financial capital of India has great concern about the economic development of the country [15]-[17]. Due to migration of people from all over the country in search of employment and trade, the population of the city is growing very fast. The city is surrounded by sea, hills and creeks and therefore has limitations on horizontal growth as well as to provide required infrastructural facilities due to scarcity of land. The existing drainage system of Mumbai city has a network of roadside surface drains, an underground drainage system in the island city, major and minor nallah discharging storm water, either into four main rivers or directly into the creek and finally to the Arabian sea [13] [18]. Being a coastal city, while designing the drainage system, there are limitations on depth of the storm water drainage system due to the tidal effect and water levels at discharge point. Existing storm water drainage system of Mumbai city have 45 outfalls below mean sea level, 135 outfalls above mean sea level but below high tide level and 6 outfalls above high tide level [19]. On $26^{\text {th }}$ July 2005 , Mumbai city experienced extreme rainfall event with highest rainfall intensity of $190.3 \mathrm{~mm} / \mathrm{hr}$ and total rainfall of $944.2 \mathrm{~mm}$ in 24 hours period coinciding with highest tide level. There was severe loss of lives and huge economic losses [15] [16] [19]. After deluge of $26^{\text {th }}$ July 2005, Municipal Corporation of Greater Mumbai (MCGM) has installed total 60 automatic weather stations all over the city which records rainfall as well as other weather data at an interval of 15 minutes. Thus, considering the importance of the city and vulnerability to flooding, for proper designing of the drainage system, knowledge of proper rainfall intensity for different return periods is necessary.

\section{Data Used in the Analysis}

Before $26^{\text {th }}$ July 2005 floods, there were only two rain gauge stations in Mumbai. The observed daily rainfall data for a period of 108 years (1901 to 2008) from Colaba rain gauge station, and 58 years (1951 to 2008) from the Santacruz rain gauge station were used [13] in deriving the IDF curves using the equation given by Kothyari 

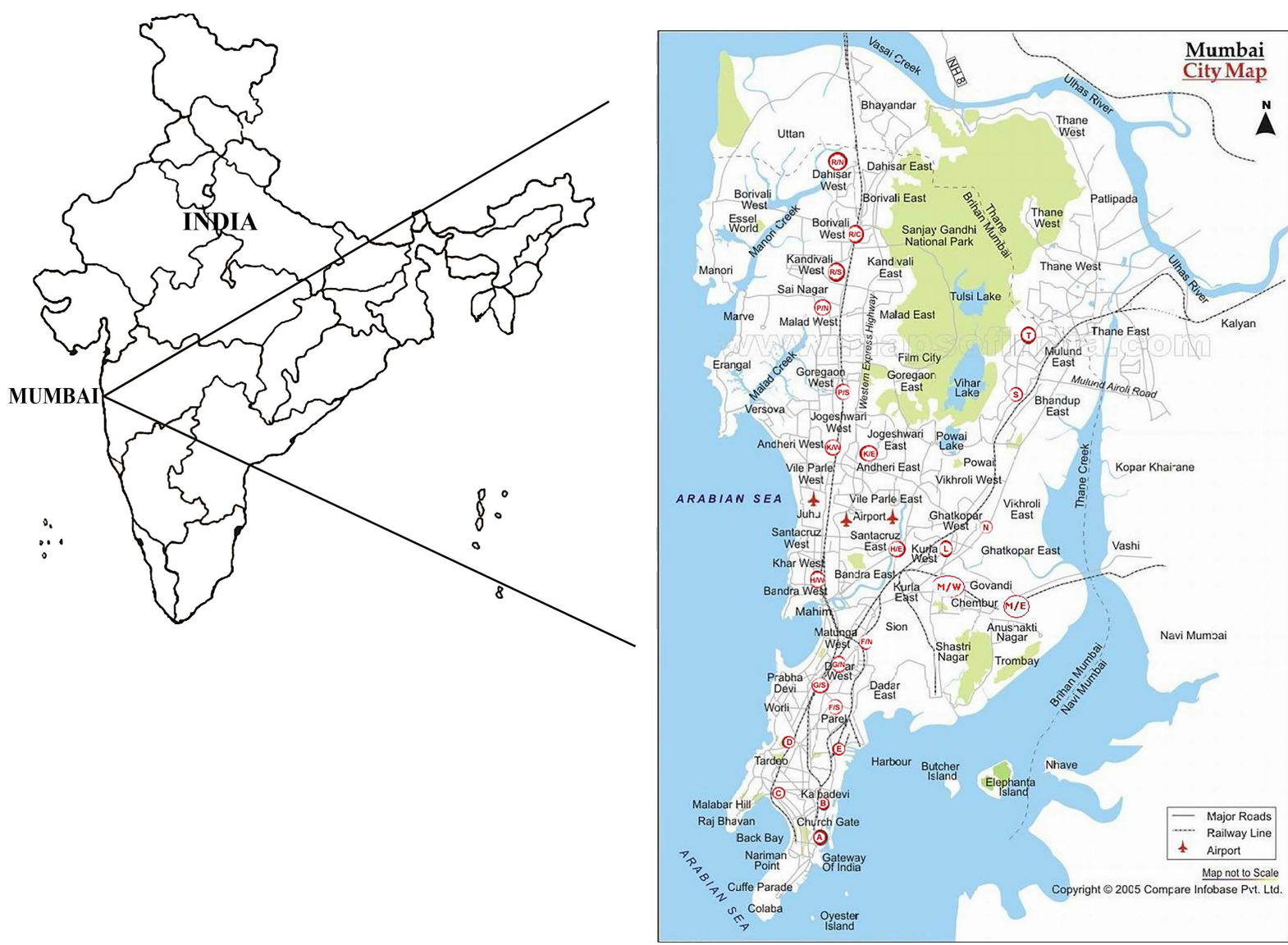

Figure 1. Location map of Mumbai city (source:

http://www.mcgm.gov.in/irj/portal/anonymous?NavigationTarget=navurl://ce7407c74001ac932426502e58da0827).

and Garde [9] as well as from the modified equation. The hourly rainfall data from 1969 to 2008 for both rain gauge stations [13] was used for deriving the IDF curves by the annual maxima method. The rainfall data has been collected from the Indian Meteorological Department (IMD) Pune as well as from the Municipal Corporation of Greater Mumbai (MCGM).

\section{Methodology}

The statistical analysis of daily as well as hourly rainfall data was carried out using Gumbel distribution [13]. The hourly rainfall at the Colaba rain gauge varies from $28.3 \mathrm{~mm} / \mathrm{hr}$ to $113 \mathrm{~mm} / \mathrm{hr}$, whereas at the Santacruz, it varies from $27 \mathrm{~mm} / \mathrm{hr}$ to $190 \mathrm{~mm} / \mathrm{hr}$ [27]. Basic statistical results of an hourly rainfall data series were carried out [27]. On $26^{\text {th }}$ July 2005, IMD at Santacruz rain gauge station recorded $944 \mathrm{~mm}$ of total rainfall in 24 hours time (Figure 2).

The maximum intensity of rainfall recorded was $190.3 \mathrm{~mm} / \mathrm{hr}$ during 14.30 to 15.30 . The Colaba rain gauge station which is within $23 \mathrm{~km}$ apart recorded only $74 \mathrm{~mm}$ of total rainfall on the same day [15] [19]. To ascertain the effects of these changing rainfall pattern, IDF curves for a Santacruz rain gauge station has been developed by including as well as excluding the rainfall on $26^{\text {th }}$ July 2005.

In this study, annual maximum daily method [20] is used in the IDF development. The step by step procedure used is given below.

- Find out year wise annual maximum daily rainfall series.

- Rank $(m)$ the rainfall totals.

- Find out return periods $(T)$.

$$
T=(N+1) / m
$$




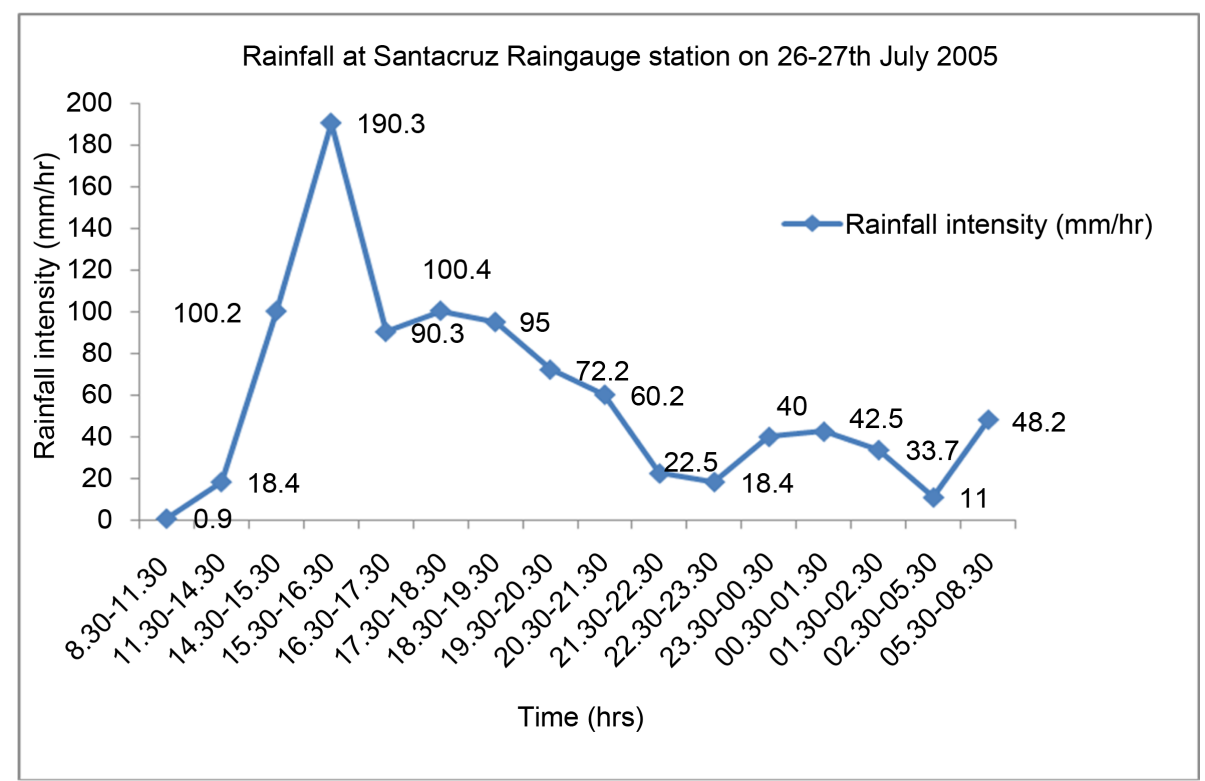

Figure 2. Rainfall at the Santacruz rain gauge station on 26-27 ${ }^{\text {th }}$ July 2005 (FFC, 2006).

where $N$ is the number of years data.

- Plot the graph of rainfall depth $\mathrm{v} / \mathrm{s}$ return period on semi log paper.

- Find out the equation of regression line to find out precipitation depth.

$$
R_{24}^{2}=P_{(m m)}=a \ln (T)+b
$$

where, $P$ = maximum daily precipitation.

Find out rainfall intensity for different return periods and different durations by using formulas as described below.

\subsection{IDF Curves by Kothyari and Garde's Method}

Kothyari and Garde [9] developed a formula to derive IDF relationship for India by analyzing the rainfall data from 78 rain gauge stations across India. The generalized relationship with realistic estimates of rainfall proposed by them for various zones of India is [9]

$$
I_{t}^{T}=C \frac{T^{0.20}}{t^{0.71}}\left(R_{24}^{2}\right)^{0.33}
$$

where, $I_{t}^{T}$ rainfall intensity in $\mathrm{mm} / \mathrm{hr}$; $T$ return period in years and $t$ duration of rainfall in hr., $R_{24}^{2}$ is $24 \mathrm{hr}$, a two-year rainfall in mm. Here values of constant $C$ in different Geographical Regions of India proposed by them are given in the Table 1. Mumbai being in western India, the value of $C$ can be taken as 8.3 for analysis of rainfall.

In the above equation, the value of $R$ (mean annual rainfall) is taken as constant as $24 \mathrm{hr}$ rainfall and 2-year return period to find out the rainfall intensities for the shorter time durations with respect to different return periods $(T)$. IDF curves with the above equation have been developed by analyzing the rainfall data of an annual daily maximum series [22] for the Colaba rain gauge station (Figure 2). The same equation is used to derive IDF rainfall curve for the Santacruz rain gauge station [22]. The developed IDF rainfall curves for the Santacruz rain gauge station are shown in Figure 3 and Figure 4 respectively, with and without $26^{\text {th }}$ July 2005 rainfall. The IDF curves derived by using the Equation (3) as given by Kothyari and Garde [9], it has been observed that for 100-year return period [23], the rainfall intensity at Colaba (Figure 3) is $112.48 \mathrm{~mm} / \mathrm{hr}$ and at the Santacruz rain gauge station with and without considering the rainfall on $26^{\text {th }}$ July 2005 (Figure 4 and Figure 5 respectively) is $117.65 \mathrm{~mm} / \mathrm{hr}$ and $117.39 \mathrm{~mm} / \mathrm{hr}$ respectively.

Thus, IDF curves established by equation given by Kothyari and Garde are not compatible with the rainfall on 
26th July 2005 in Mumbai with an intensity of about 190 mm/hr as well as today’s changing hydrological conditions and extremities of the rainfall event.

\subsection{IDF Curves by Probability Distribution for Annual Maximum Rainfall}

In this method, the rainfall frequency analysis of the maximum rainfall depth corresponding to hourly storm

Table 1. Values of constant $C$ in different geographical regions of India (source: Kothyari and Garde; 1992) [9] [21].

\begin{tabular}{ccc}
\hline Geographical region & Zone & Value of $C$ \\
\hline Northern India & 1 & 8.0 \\
Central India & 2 & 7.7 \\
Western India & 3 & 8.3 \\
Eastern India & 4 & 9.1 \\
Southern India & 5 & 7.1 \\
\hline
\end{tabular}

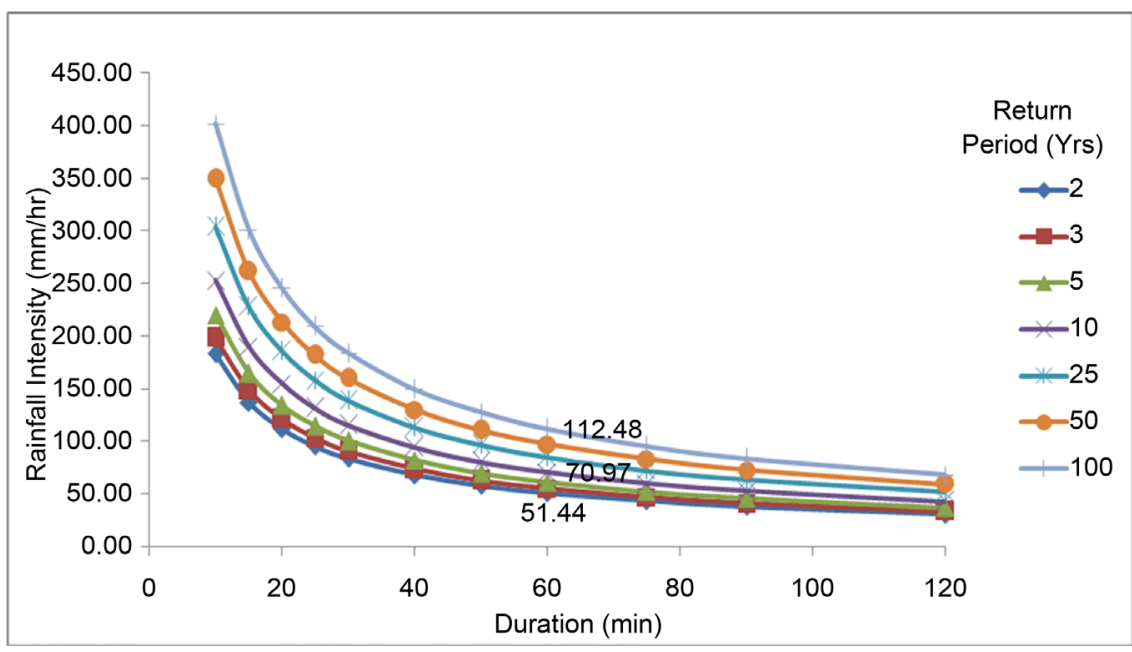

Figure 3. IDF curves for the Colaba with Kothyari and Garde’s method-constant $R$.

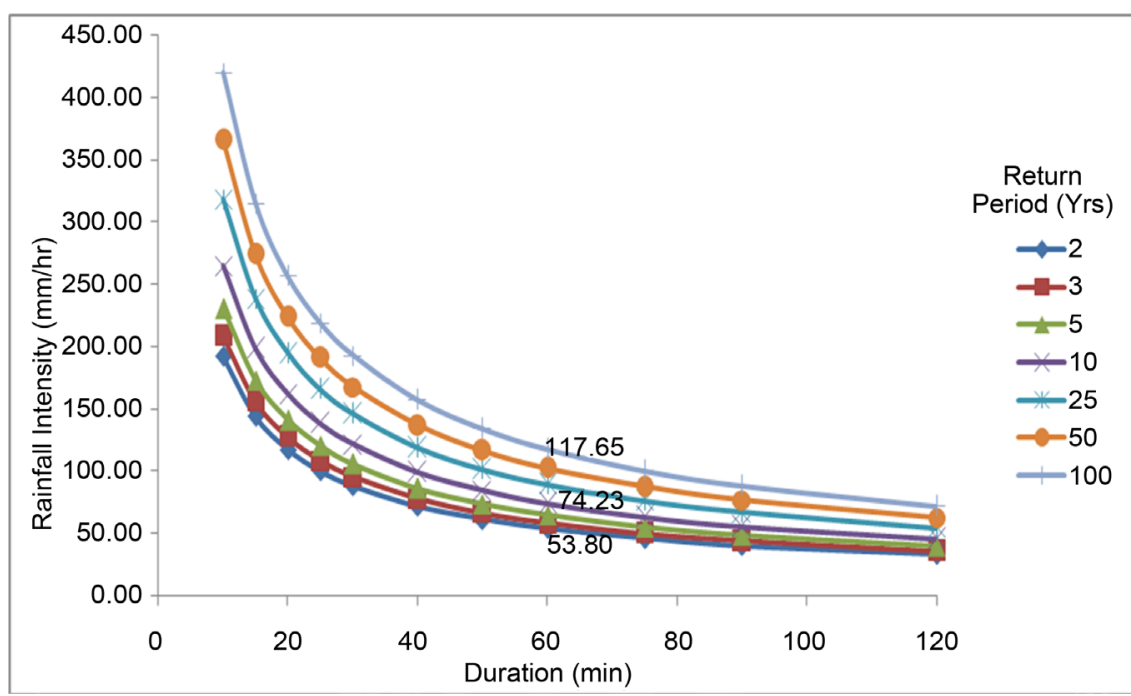

Figure 4. IDF curves for the Santacruz with Kothyari and Garde's method-constant $R$ with extreme rainfall of 2005. 


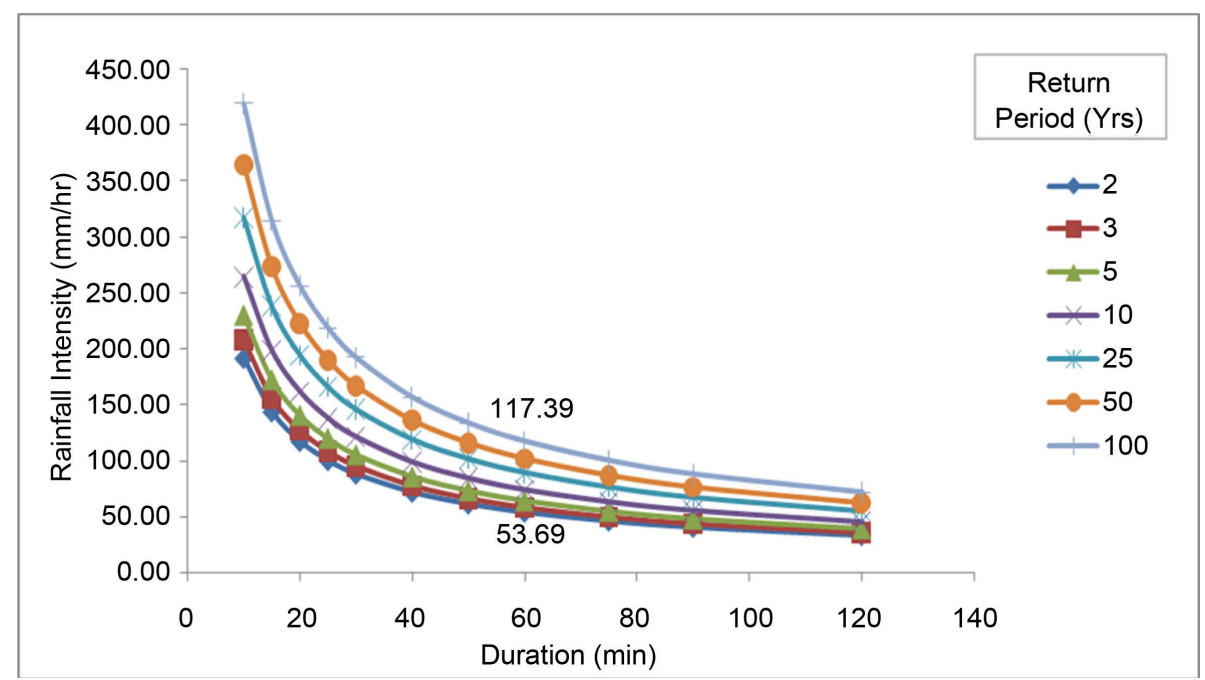

Figure 5. IDF curves for the Santacruz with Kothyari and Garde's method-constant $R$ without extreme rainfall of 2005.

durations (1969-2008) were determined for each year of data for both the rain gauge stations, and then the results were ranked in descending order with the highest intensity taking the value of one in the rank. Probability function was used to fit the data. Rainfall frequency analysis for different return periods was done by using the extreme value Gumbel Type I distribution [24]-[27]. Frequency of precipitation $X_{T}$ (in mm) for each duration having the specified return period $T$ (year) is given by Equation (4) [21] as below.

$$
X_{T}=\bar{X}_{t}+K \sigma_{n-1}
$$

where, $\bar{X}_{t}=$ mean of annual maximum depth; $\sigma_{n-1}=$ standard deviation of annual maximum depths; and, $K=$ Frequency factor.

For the Gumbel distribution, the value of $K$ is given in the Equation (5) as below [21].

$$
K=-\left(\frac{\sqrt{6}}{\pi}\right)\left(0.5772+\ln \left(\ln \left(\frac{T}{T-1}\right)\right)\right)
$$

For the rain gauge stations, statistical analyses were carried out with mean and standard deviations and value of $K$ of annual maximum depths having various durations were derived. The IDF relationships obtained by an annual maximum method for the Colaba rain gauge station is shown in Figure 6 and for the Santacruz rain gauge station with and without considering 26th July 2005 rainfall are shown in Figure 7 and Figure 8 respectively.

As per the derived IDF rainfall curves, rainfall intensity for the 100 -year return period is $124.86 \mathrm{~mm} / \mathrm{hr}$ for the Colaba rain gauge station and $160.11 \mathrm{~mm} / \mathrm{hr}$ and $132.72 \mathrm{~mm} / \mathrm{hr}$ respectively with and without considering $26^{\text {th }}$ July 2005 rainfall for the Santacruz rain gauge station.

\section{Results and Discussion}

In the present study, it was aimed to develop the IDF curves for the rainfall in the Mumbai city in changing hydrologic conditions. The IDF curves developed by using the Equation (3) as given by Kothyari and Garde [9], it had been observed that for the 100-year return period [23], the rainfall intensity at Colaba (Figure 3) is 112.48 $\mathrm{mm} / \mathrm{hr}$ and at the Santacruz rain gauge station with considering and excluding the rainfall of $26^{\text {th }}$ July 2005 (Figure 4 and Figure 5 respectively) is $117.65 \mathrm{~mm} / \mathrm{hr}$ and $117.39 \mathrm{~mm} / \mathrm{hr}$ respectively. However, as per past rainfall record, Mumbai has experienced $190 \mathrm{~mm} / \mathrm{hr}$ rainfall intensity in July 2005. Thus the IDF curves developed by using equation given by Kothyari and Garde [9], by keeping value of $R$ constant as 2-year return period, does not show the proper results in the recently changing hydrologic conditions for the Mumbai city. In view of this, to obtain better results, the Equation (3) was modified and the new Equation (6) is given as below. 


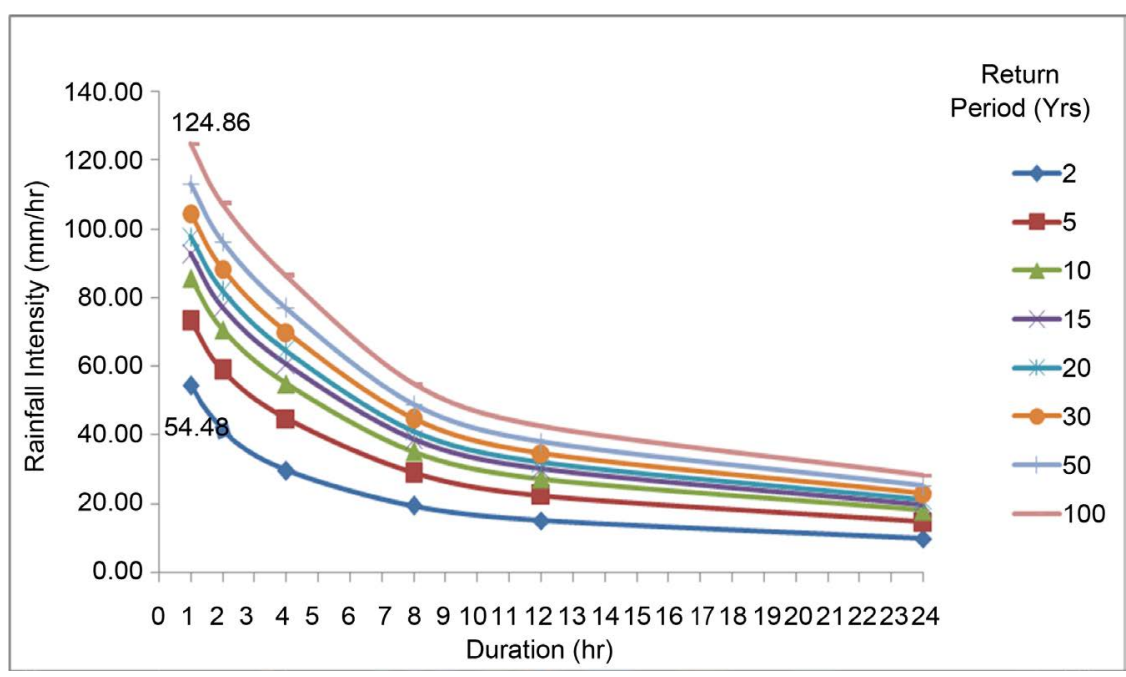

Figure 6. IDF curves for the Colaba by probability distribution for annual maximum rainfall.

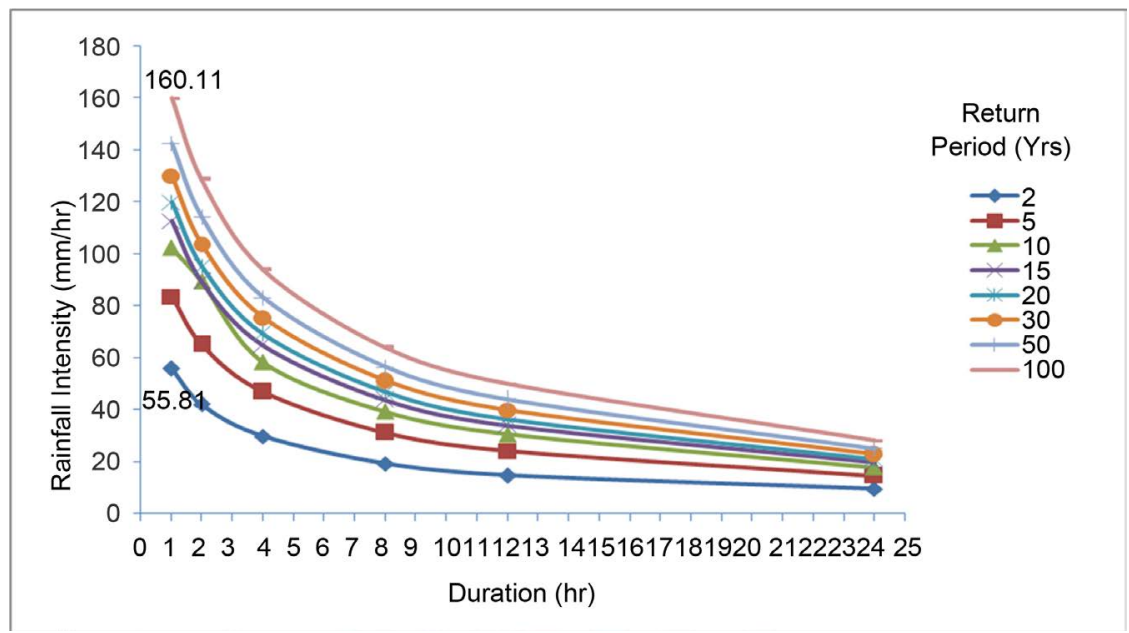

Figure 7. IDF curves for the Santacruz by probability distribution for annual maximum rainfall with $26^{\text {th }}$ July 2005 Rainfall.

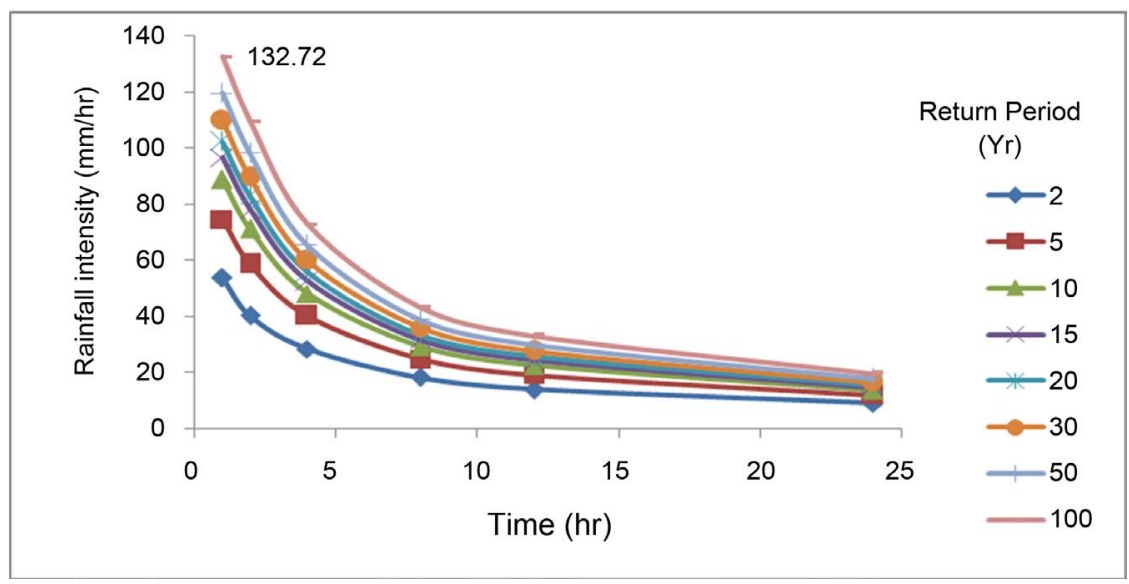

Figure 8. IDF curves for the Santacruz by probability distribution for annual maximum rainfall without $26^{\text {th }}$ July 2005 Rainfall. 


\section{Modified Kothyari and Garde's Method}

In the changing climatic conditions, to avoid urban flooding and to take appropriate care, proper knowledge of rainfall intensity should be available for the proper and efficient design of the storm water drainage system. As discussed above, to obtain better results, the Equation (3) was modified and the new equation is obtained as:

$$
I_{t}^{T}=C \frac{T^{0.20}}{t^{0.71}}\left(R_{24}^{T}\right)^{0.33}
$$

In the above equation, the value of an $R$ will vary with the return period $(T)$ to derive the rainfall intensity for smaller durations. The IDF curves developed by using the above Equation (6), for the Colaba rain gauge station (Figure 9), and with considering and excluding the rainfall of $26^{\text {th }}$ July 2005 for the Santacruz rain gauge station are shown in Figure 10 and Figure 11 respectively.

From the modeled IDF curves by the above new equation, it had been observed that for 100-year return period, the rainfall intensity at the Colaba is $164.56 \mathrm{~mm} / \mathrm{hr}$ and at the Santacruz rain gauge station with considering and excluding the rainfall of $26^{\text {th }}$ July 2005 is $176.37 \mathrm{~mm} / \mathrm{hr}$ and $160.35 \mathrm{~mm} / \mathrm{hr}$ respectively, which shows the better results as compared with the past rainfall records for a Mumbai city. As per IDF curves modeled by the probability distribution for annual maximum rainfall, the rainfall intensity [28] at the Colaba is $124.86 \mathrm{~mm} / \mathrm{hr}$ and at Santacruz rain gauge station with and without considering $26^{\text {th }}$ July 2005 rainfall is $160.11 \mathrm{~mm} / \mathrm{hr}$ and 132.72 $\mathrm{mm} / \mathrm{hr}$ respectively. Thus, comparing the results obtained from the equation given by Kothyari and Garde, the

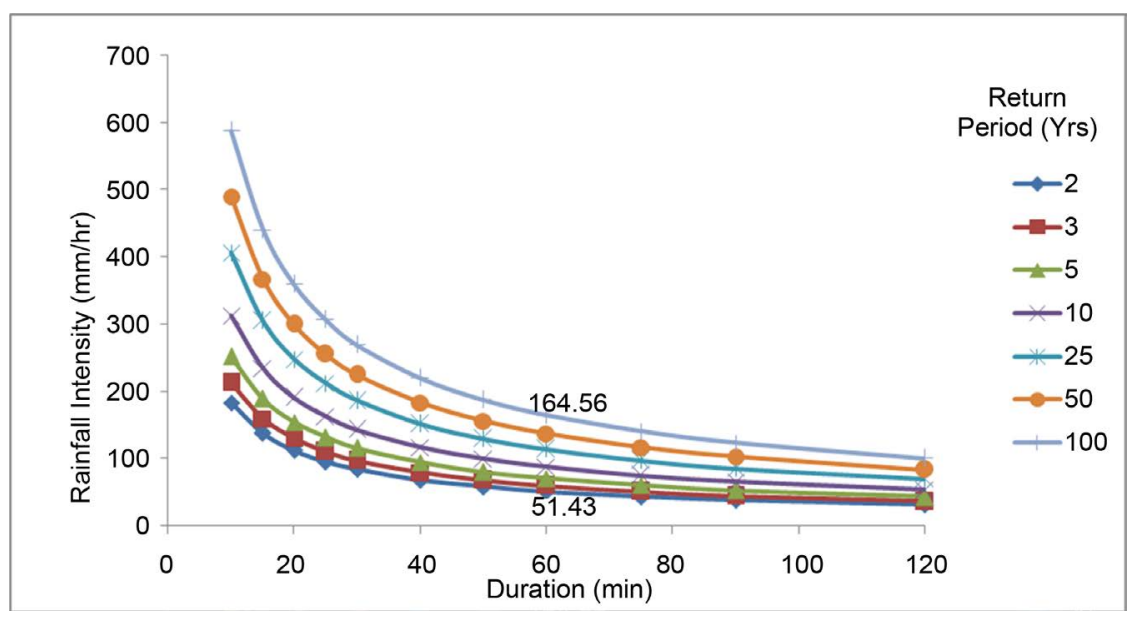

Figure 9. IDF curves for the Colaba with modified Kothyari and Garde’s method-varying $R$.

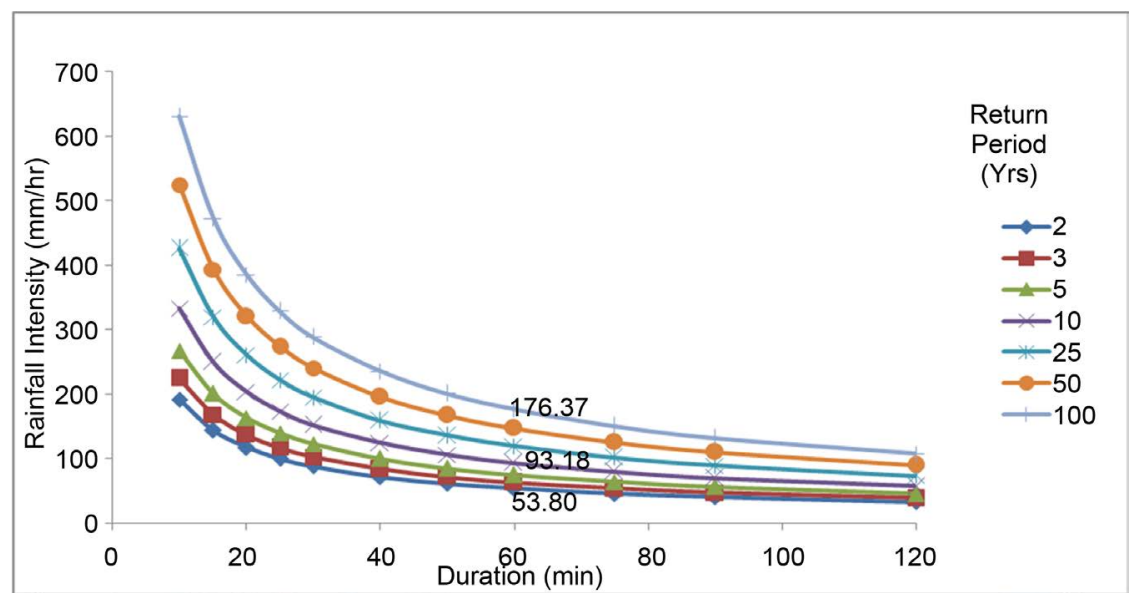

Figure 10. IDF curves for the Santacruz with modified Kothyari and Garde's methodvarying $R$ with 2005 rainfall. 


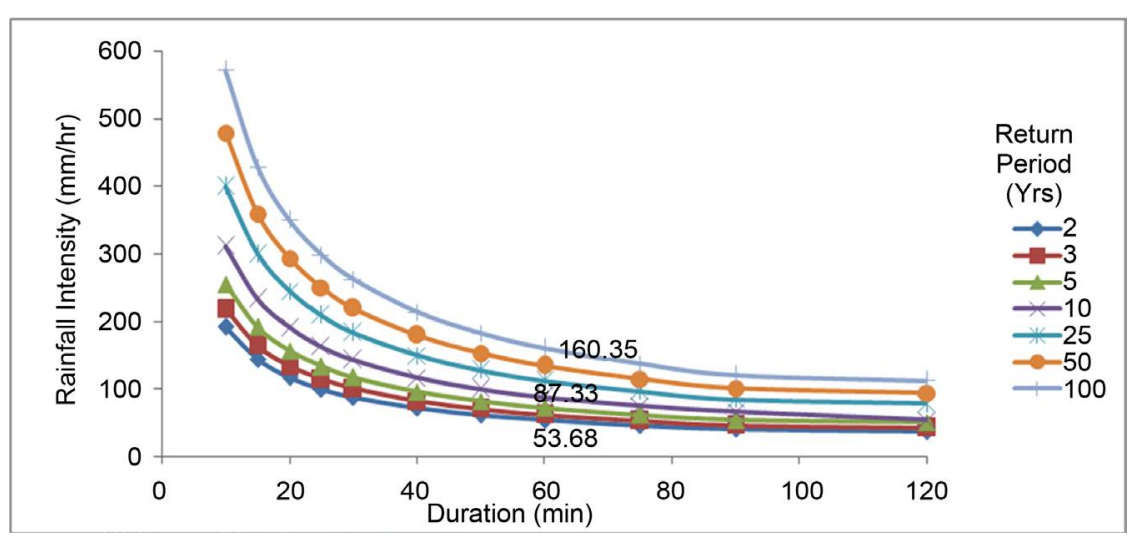

Figure 11. IDF curves for the Santacruz with modified Kothyari and Garde’s methodvarying $R$ without 2005 rainfall.

new modified equation and an annual maximum rainfall method, IDF curves established by using the new modified equation shows better results in the changing hydrologic conditions as observed on $26^{\text {th }}$ July 2005 in Mumbai. Also, from the rainfall analysis, it was observed that the intensities for all frequencies and durations of storms are generally lower for Colaba as compared to those at Santacruz.

\section{Conclusion}

Due to change in global mean temperature and hydrological changes, the higher frequency of rainfall may occur in the future as observed in the last few years in many parts of the world. Mumbai being the coastal city, surrounded by sea and creek, is vulnerable to flooding due to many reasons such as high intensity of rainfall, high tides, loss of drainage capacity due to design faults, development of reclaimed areas and improper knowledge and adoption of intensity of rainfall in designing the drainage system. For the design of appropriate drainage system, IDF curves are to be considered. The IDF relationships developed in the present study can be used effectively in designing the new drainage system and in modifying or replacing the old ones. As observed, the IDF curves derived by modifying the Kothyari and Garde's equation shows good results in the changing hydrologic conditions as reported on $26^{\text {th }}$ July 2005 in Mumbai. Alternatively, the IDF relationship developed for Santacruz rain gauge station may be used for the entire city, since it is located centrally and also being expressing the higher intensities of rainfall, the design would be safer to avoid flooding in the future.

\section{Acknowledgements}

The authors are grateful to the Municipal Corporation of Greater Mumbai and also grateful to India Meteorological Department for providing the rainfall data of Santacruz and Colaba rain gauge stations, Mumbai, India for this study.

\section{References}

[1] Chawathe, S.D., Shinde, U.R., Fadanvis, S.S. and Goel, V.V. (1977) Rainfall Analysis for the Design of Storm Sewers in Bombay. The Institution of Engineers (India) Journal-EN, 58, 14-20.

[2] Koutsoyiannis, D., Demosthenes, K. and Manetas, A. (1998) A Mathematical Framework for Studying the Rainfall Intensity-Duration-Frequency Relationships. Journal of Hydrology, 303, 215-230.

[3] Sherman, C.W. (1932) Frequency and Intensity of Excessive Rainfalls at Boston-Massachusetts. Transactions, ASCE, 95, 95l-960.

[4] Bernard, M.M. (1932) Formulas for Rainfall Intensities of Long Durations. Transactions. ASCE, 96, 592-624.

[5] Kuichling, E. (1889) The Relation between the Rainfall and the Discharge of Sewers in Populous Districts. Transactions of ASCE, 20, 1-60.

[6] Bell, F.C. (1969) Generalized Rainfall-Duration-Frequency Relationships. Journal of Hydraulic Division, ASCE, 95, 311-327.

[7] Chen, C.L. (1983) Rainfall Intensity-Duration-Frequency Formulas. Journal of Hydraulic Engineering, ASCE, 109, 
1603-1621. http://dx.doi.org/10.1061/(ASCE)0733-9429(1983)109:12(1603)

[8] Yu, P.S., Yang, T.C. and Lin, C.S. (2004) Regional Rainfall Intensity Formula Based on Scaling Property of Rainfall. Journal of Hydrology, 295, 108-123. http://dx.doi.org/10.1016/j.jhydrol.2004.03.003

[9] Kothyari, U.C. and Garde, R.J. (1992) Rainfall Intensity-Duration-Frequency Formula for India. Journal of Hydraulic Engineering, ASCE, 118, 323-336. http://dx.doi.org/10.1061/(ASCE)0733-9429(1992)118:2(323)

[10] Vyver, H.V.de and Demaree, G.R. (2010) Construction of Intensity-Duration-Frequency Curves at Lubumbashi, Congo, under the Hypothesis of Inadequate Data. Hydrological Sciences Journal, 55, 555-564. http://dx.doi.org/10.1080/02626661003747390

[11] Al-anazi Khalid, K. and El-Sebaie Ibrahim, H. (2013) Development of Intensity-Duration-Frequency Relationships for Abha City in Saudi Arabia. International Journal of Computational Engineering Research, 3, 58-65.

[12] Guo, Y. (2006) Updating Rainfall IDF Relationships to Maintain Urban Drainage Design Standards. Journal of Hydrologic Engineering, 11, 506-509. http://dx.doi.org/10.1061/(ASCE)1084-0699(2006)11:5(506)

[13] Zope, P.E., Eldho, T.I. and Jothiprakash, V. (2012) Spatio-Temporal Analysis of Rainfall for Mumbai City, India. Journal of Environmental Research and Development, 6, 545-553.

[14] Sherly, M., Karmakar, S., Chan, T. and Rau, C. (2016) Design Rainfall Framework Using Multi-Variate Parametric-Nonparametric Approach. Journal of Hydrologic Engineering, 21, 04015049: 1-17. http://dx.doi.org/10.1061/(ASCE)HE.1943-5584.0001256

[15] Gupta, K. (2007) Urban Flood Resilience Planning and Management and Lessons for the Future: A Case Study of Mumbai, India. Urban Water Journal, 4, 183-194. http://dx.doi.org/10.1080/15730620701464141

[16] Gupta, K. and Lokanadham, B. (2008) Characterization of Spatial and Temporal Distribution of Monsoon Rainfall in Mumbai. Proceeding of 11th International Conference on Urban Drainage, Edinburgh, 31 August-5 September 2008.

[17] Jenamani, R.K., Bhan, S.C. and Kalsi, S.R. (2006) Observational/Forecasting Aspects of the Vent that Caused a Record Highest Rainfall in Mumbai. International Journal of Current Science, 90, 1344-1362.

[18] Zope, P.E., Eldho, T.I. and Jothiprakash, V. (2015) Impacts of Urbanization on Flooding of Coastal Urban Catchment: A Case Study of Mumbai City, India. Natural Hazards, 75, 887-908. http://dx.doi.org/10.1007/s11069-014-1356-4

[19] FFC (Fact Finding Committee) Report on Mumbai Floods (2006) Maharashtra State Government Committee Report, 31-130.

[20] Kolsky, P. (1998) Storm Drainage-An Engineering Guide to the Low Cast Evaluation of System Performance. Intermediate Technology Publications Ltd., London. http://dx.doi.org/10.3362/9781780446059

[21] Goel, N.K. and Sarkar, S. (2007) Regional Rainfall Intensity-Duration-Frequency Relationship. NTPC Sponsored Training Course on Design Flood Analyses for Hydropower Projects, August 20-25 2007, IIT Roorkee.

[22] Vita, P.D., Allocca, V., Manna, F. and Fabbrocino, S. (2012) Coupled Decadal Variability of the North Atalantic Oscillation, Regional Rainfall and Karst Spring Discharges in the Campania Region (South Italy). Hydrology and Earth System Science, 16, 1389-1399. http://dx.doi.org/10.5194/hess-16-1389-2012

[23] Wang, D., Hagen, S.C. and Alizad, K. (2013) Climate Change Impact and Uncertainty Analysis of Extreme Rainfall Events in the Apalachicola River Basin, Florida. Journal of Hydrology, 480, 125-135. http://dx.doi.org/10.1016/j.jhydrol.2012.12.015

[24] Antigha, R.E. and Ogarekpe, N.M. (2013) Development of Intensity Duration Frequency Curves for Calaba Metropolis, South-South Nigeria. The International Journal of Engineering and Sciences (IJES), 2, 39-42.

[25] BRIMSTOWAD (2009) Storm Water Drain Update Report Submitted by MWH to Municipal Corporation of Greater Mumbai (MCGM).

[26] Elsebaie, I.H. (2012) Developing Rainfall Intensity-Duration-Frequency Relationship for Two Regions in Saudi Arabia. Journal of King Saud University-Engineering Sciences, 24, 131-140. http://dx.doi.org/10.1016/j.jksues.2011.06.001

[27] Rasel, M.M. and Islam, M.M. (2015) Generation of Rainfall Intensity-Duration-Frequency Relationship for NorthWestern Region in Bangladesh. IOSR Journal of Environmental Science, Toxicology and Food Technology, 9, 41-47.

[28] Naghettini, M. (2000) A Study of the Properties of Scale Invariance as Applied to Intensity-Duration-Frequency Relationship of Heavy Storms. Building Partnership 1-8. http://dx.doi.org/10.1061/40517(2000)139 


\section{Submit or recommend next manuscript to SCIRP and we will provide best service for you:}

Accepting pre-submission inquiries through Email, Facebook, Linkedin, Twitter, etc A wide selection of journals (inclusive of 9 subjects, more than 200 journals)

Providing a 24-hour high-quality service

User-friendly online submission system

Fair and swift peer-review system

Efficient typesetting and proofreading procedure

Display of the result of downloads and visits, as well as the number of cited articles

Maximum dissemination of your research work

Submit your manuscript at: http://papersubmission.scirp.org/ 